inclosed in a lead pipe, and to the columns by two cables of seven strands of No. I2. A separate return cable runs from each lamp to the hut, where it is connected to the necessary resistances, made of strip iron, and from there back to the dynamo through two cables of nineteen No. r2's. There is altogether very nearly a ton of copper in the various leads and branches. Besides these leads the centre chamber is connected to the circuit of the Sun light machine, so that, should any accident occur to the main circuit or michine, Sun lights could be substituted for the hand lamps.

As the falling spray cuts off the light from below when the jets are at their highest, a light is placed in the top of the clock tower to illuminate the top of the jets. This light is a focus-keeping Siemens automatic lamp, and takes a current of fifty amperes, supplied by a small Crompton-Burgin machine. The lamp is inclosed in a cast-iron casing swung on trumnions, and in front of it is a fifth-order holophotal lens by Messrs. Siemens.

The various coloured glasses are fixed in frames or sashes arranged with counterweights, in the same way as an ordinary window. Some of the best effects of colour are also obtained by sheets of gelatine, of which a large number are fastened end to end, and fixed to two rollers, so that they can be wound from the one to the other, and thus passed through the beam of light.

As the men in the centre chamber cannot see the effects they produce, it is necessary to direct them from the outside, and this is effected by an elaborate system of electric bells and disks, which are worked from the clock chamber below the last-described holophote. In this chamber sits Sir Francis Bolton, with a treble row of "pushes" in front of him, all labelled, by touching any of which a corresponding disk or bell is worked in the island. There are four bells - a call bell, an "on" bell, an "off" bell, and a lamp bell-and two indicator boards with eight disks each, and one with four. One board is for the water valves, which are each painted a different colour, with the corresponding colour on the disk, and the second board for the coloured glasses over the holophotes. The disks on the small board refer to the corner lamps, and by their means Sir Francis can direct any colour to be placed over any one of the lamps by touching the push corresponding to the lamp and the push marked with the colour which he wishes to show. The working of the holophote at the top of the clock is directed in the same way.

\section{EXPERIMENTS WITH COAL-DUST AT NEUNKIRCHEN IN GERMANY}

$\mathrm{D}$

URING the course of the last summer the Royal Prussian Fire-damp Commission has carried out a series of experiments in the Saarbricken mining district with the view of ascertaining the influence which coaldust has, alone and in conjunction with firc-damp, in propagating explosions in mines. The apparatus and the mode of experiment were suggested by retired Bergwerksdirector and Bergassessor Hilt, of Aix-la-Chapelle, who is a member of the Commission, and the results hitherto obtained have been of the most interesting kind.

The experiments are conducted at the Royal Coal Mine, König, near Ncunkirchen, where there is a blower of fire-damp at a depth of 131 yards below the surface. The quantity of fire-damp given off by this blower amounts to about 0.9 cubic foot per minute, consisting of $\$ 6$ per cent. of light carburetted hydrogen mixed with air, \&c. It has been in existence for the last two years. The firedamp is brought a distance of 1200 yards in pipes, and collected in a small gasometer whose capacity is 176 cubic feet.

Dr. Ad. Gurlt of Bonn lately called my attention to the fact that over two hundred experiments made with this apparatus on a large scale had proved the correctness of my theory of great collicry explosions (Proc. Roy. Soc., vol. xxiv. p. 354, \&c.), and at the same time suggested that a visit to Neunkirchen would be of interest.

Accordingly I proceeded to the scene of the experiments on October 25, accompanied by Mr. Wm. Thomas Lewis, one of the members of the Royal Commission on Accidents in Mines, and we were met there by Dr. Gurlt, who had travelled from Bonn for the purpose, and by Herren Prietze, Nasse, Margraf, and Kreuser, directors and assistant-directors of König Grube and other Royal mines of the neighbourhood. Herr Margraf, under whose superintendence all the experiments are and have been made, has most kindly furnished me with a detailed description of the apparatus and of the experiments witnessed by Mr. Lewis and myself, and I am glad to avail myself of, and shall endeavour to reproduce, his account as nearly as may be, allowance being made for the difficulties of exact translation.

The experiments are made in a horizontal wooden gallery 167 feet long, closed at one end, and having a horizontal branch gallery 33 feet long standing out at right angles to it at a distance of 93 feet from its closed end. Both the main gallery and the branch consist of elliptical rings of double 'T-iron lined internally with planks I 6 inch thick, which abut closely together and are grooved and feather-jointed lengthwise. The greater axis of the ellipse stands vertically, and is about 5 feet 7 inches long; the lesser axis is 3 feet II inches long. The main and branch galleries are both embedded in the pit-heap to such a depth that the rubbish is level with their top on one side and reaches to threequarters of their height on the other side. Along the exposed part of the latter side there is a row of windows, thirty-two, in the main gallery, and three in the branch gallery, situated somewhat more than a yard apart. They are formed of sheets of glass about $\frac{2}{3}$ inch thick set in cast-iron frames. There are also a number of openings in the top of the main gallery, one of which, near the closed end, is an ordinary man-hole, which can be closed by a man-hole door like that of a boiler, and serves as a means of ingress and egress. The others are circular, about 9 inches in diameter, and are lightly closed with wooden plugs attached to chains, which act as safety valves. All these openings assist in the removal of afterdamp after an explosion.

The closed end of the main gallery is sunk about 3 feet 9 inches into a block of masonry whose dimensions are 12 feet 4 inches long, 9 feet 9 inches wide, and $I_{3}$ feet high. Seven cast-iron camnon, with a bore similar to that of a shot-hole in hard ground, are built into the block in the position shown in the figure oppositc, so that their mouths are flush with the face.

There are two holes near the top, two near the bottom, and three in the middle, grouped symmetrically in relation to the two axes of the ellipse. The middle hole is 37 inches deep by 1.57 inch in diameter; the others are $31 \frac{1}{2}$ inches deep by 1.37 inch in diameter. The axes of the two upper and of the two lower holes are placed in such a position that they form the angles of a four-sided regular prism whose apex is situated in the axis of the main gallery at a distance of $16^{\circ} 4$ feet from the face. The axes of the thrce middle holes constitute a bundle of rays which meet at the same point as the last. Wooden hoops projecting inwards from the sides are placed at various distances apart in the main gallery within the first $65 \frac{1}{2}$ feet from the face. By fastening cloth diaphragms to these hoops, compartments of various capacity can be formed, that of the first next the face being 705 cubic feet.

The shots are fired electrically with Abegg's fuses by means of an exploder made by Mahler and Eschenbacher of Vienna. The charge, which consists of 230 grammes, or about half a pound, of powder, occupies a length of 8.64 inches in the central hole, leaving room for rather 
over 28 inches of stemming, and $1 \mathrm{I}$ inches in the other holes, leaving about 20 inches for stemming.

The coal-dust is strewn upon the floor of the gallery from the face towards the open end in a layer of about I'I7 inch thic's immediately before firing the shots. The weight of dust in each ten yards of length is about thirty pounds. It has been found in practice that, notwithstanding the upward direction of their axes, the shots next the floor produce the greatest disturbance of the coal-dust and give rise to longer coal-dust flames than any of the others.

In all the experiments witnessed by Mr. Lewis and myself, one shot-hole cnly, namely, one of the two next the floor, was charged and fired. The charge consisted of 230 grammes of blasting-powder each time, and the tamping was damp clay. Both ends of the branch gallery were closed with a double board brattice 1.96 inch thick.

In the first experiment neither coal-dust nor fire-damp was employed, and the flame of the shot was seen through the windows to be a little over i 3 feet long.

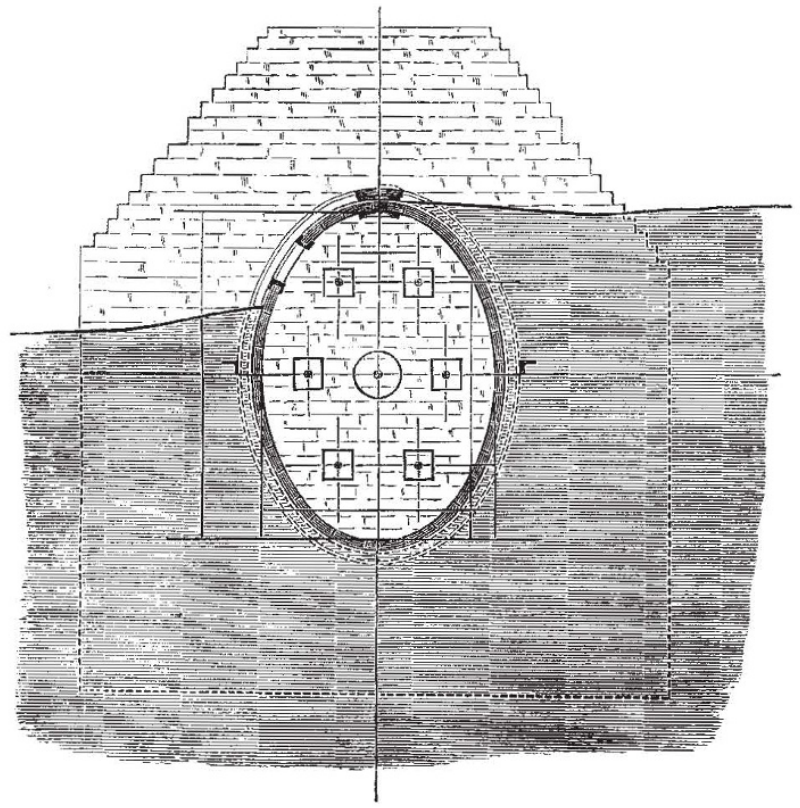

In the second experiment a length of 65 feet of the floor of the main gallery was strewn with coal-dust from Camphausen Colliery in the Saarbrücken mining district. The shot gave rise to a loud detonation, and the resulting flame filled the gallery to a distance of $88 \frac{1}{2}$ feet. When the thick black after-damp had been drawn off by means of two of Korting's exhausters, placed over two of the safety-holes and worked with compressed air, it was found that the inner brattice of the branch gallery had been bro'en, and small globules of coke were observed lying on the surface of the remaining coal-dust.

In the third experiment a length of 130 feet of the floor of the main gallery was strewn with coal-dust from Pluto Mine in Westphalia. When the shot was fired, the flame traversed the whole length of the gallery with great velocity, and came out at the open end to a distance of I 6 feet, being thus altogether 183 feet long. Notwithstanding the entire absence of fire-damp, this was a true explosion of the most violent kind, and the clouds of afterdamp which streamed from every opening darkened the air in the neighbourhood of the gallery for two or three minutes. The brattice at the inner end of the branch gallery had not been replaced before this experiment, and the one at its outer end was broken into small frag- ments, some of which were thrown to a distance of 115 feet. The flame was also seen to emerge from the branch gallery to a distance of several yards. The coal-dust remaining on the floor after the explosion was covered with a sooty film, in which coke globules were found embedded.

The brattice at both ends of the branch gallery was now replaced, and the floor of the main gallery swept clean as usual. In the fourth and last experiment coaldust from Pluto Mine was strewn on the floor for a distance of 65 feet from the face. A diaphragm of prepared canvas was fastened in the gallery at the point where the space inclosed between itself and the face amounts to 705 cubic feet.

A volume of $35 \frac{1}{4}$ cubic feet of fire-damp was introduced into this space, and complete diffusion was effected by beating the air with cloths. The mixture of fire-damp and air thus obtained is not inflammable or explosive by itself, and shows a cap of only $1 \frac{5}{16}$ inch high on the reduced flame of a safety-lamp. The firing of the shot produced a flame 190 feet long, accompanied by a report like a thunder-clap. The inner brattice of the branch gallery was broken, and drawn several yards into the main gallery, but the outer one remained intact.

Some idea of the great force of the two last explosions may be gathered from the following facts :-An ordinary mine railway, beginning on a level with the floor of the main gallery, extends away from its open end in the direction of its length, and ascending at an angle of $4^{\circ}$. An ordinary mine waggon, loaded with iron so as to weigh altogether $55 \frac{1}{2} \mathrm{cwt}$., was standing on the rails at the mouth of the main gallery when the shots were fired. When the third shot was fired, it was driven up along the rails to a distance of 23 feet, and when the fourth shot was fired, it was literally hurled along the railway by the force of the explosion to a distance of $52 \frac{1}{2}$ feet, being driven off the rails and running on the ground for the last six feet. The boards constituting the end of this waggon next the gallery were broken, but not torn off. A small beam 4 inches square, bolted across the rails at the mouth of the gallery, so as to form a stop for the waggon, was torn from the bolts which held it, and sent flying after the train. Lastly, a shower of stones and debris was raised by the blast which swept out of the mouth of the gallery, and some of the pieces carried upwards of Ioo feet.

The foregoing facts appear to me to be well worthy of the attention of all who have any interest in the prevention of explosions in mines. W. GALLOWAY

\section{FLOWERS OUT OF SEASON}

THE untimely flowering of trees and shrubs, like the occurrence of the extraordinary gooseberry, is a subject which crops up at such regular intervals as almost to belie the epithet applied to it. Nevertheless, the very frequency of the comment is an indication that the matter is ill understood.

The ordinary time-rate for the production of new cells, new leaves, new flowers, and so on, varies as we see within wide limits. Equally obviously those limitations are imposed by the conjoint effects of inheritance and of external conditions, such as climate or food, or both. An annual plant rushes through its life in hot haste as it were: save and except in the seeds of such plants there is comparatively little building up or maturing of new tissues to be done, and proportionately still less stores of potential food to be accumulated. If, on the one hand, the requirements of such plants are less than in the case of perennials, their exigencies are, on the other hand, more pressing. What they take from the soil, or atmosphere, what power they derive from solar light and heat, must be got quickly or not at all. One illustration of this is afforded by the paucity of annual species in the Arctic regions or at high altitudes. Neither heat nor light is absolutely deficient in such situa- 